\title{
Same-sex Marriage in Argentina Tolerance and Discrimination in Political Culture
}

\author{
José Eduardo Jorge \\ Facultad de Periodismo y Comunicación Social \\ Universidad Nacional de La Plata - Argentina \\ jjorge@perio.unlp.edu.ar \\ josjorge@hotmail.com
}

Facultad de Periodismo y Comunicación Social

Diagonal 113 № 291 esq. 63

La Plata (CP 1900)

Argentina

Phone/Fax: +54 2214250133 


\begin{abstract}
The fact of Argentina being one of the first countries to legalize gay marriage has been studied all over the world. A not-so-mentioned cause is that, according to survey data, discriminatory attitudes towards homosexual people decreased noticeable in Argentina since the restoration of democracy in 1983. The evolution of these attitudes, considered as a key indicator of the value of tolerance in any society, suggests that at least some central components of political culture may change as a product of democratic exercise and not only of economic modernization. The article also revises the attitudes towards people suffering from AIDS and people with criminal records.
\end{abstract}

Key words: same-sex marriage, tolerance, diversity, political culture, democracy 


\section{Democracy and diversity}

One of the tasks of democracy consists in guaranteeing the freedom of the various groups and individuals to have their own life projects while, at the same time, making possible for them to take and feel part of the development of collective life. Democracy can in this way be conceived as a particular way of living together which simultaneously values and looks for diversity and unity. If society tries to overcome its differences from a unique conception of 'the good life', diversity suffers on behalf of unity. If, on the contrary, the different groups limit themselves to recognize and accept their differences, but they do not commit with the common construction of the collective life, society tends to split up in a group of closed communities: it is the unity, at this point, the one that suffers on behalf of diversity. Minorities, particularly, will find themselves 'tolerated', but not completely 'integrated'. Democracy, then, means to live together - and not merely coexist - in the difference.

It is inferred from this that democracy is a hard-to-reach form of common life. It is no surprise that it has only been able to be accomplished - and in a really imperfect way - in brief and specific moments in human history. In most of the societies which have existed, powerful minorities have imposed to others their own conceptions and interests. Conversely, in the history of the same democracies, the social and cultural pluralism - beyond the one strictly political - has made its own way with difficulty, when the majority groups' views has tried to obstruct or eliminate the ones belonging to the minorities that contradicted them. And, in some cases, the same minorities 
have exposed their demands in terms which meant a permanent breaking-off with the rest of the society, blocking, in this way, the road to their own integration.

Diversity is becoming a central normative value of the 21 st century's democracy, after many countries started to experiment it with increasing intensity in the second half of the preceding century. As a result of the flows of immigration and the internal diversification of the Nation-states itself, they tend more and more to recognize themselves as multicultural societies. The new democratic ideal does not ask the State for working to create a homogeneous society, deleting the ethnic, linguistic, religious or life-style differences, but it asks for their recognition, value and protection. Social and economic equality keeps on being a general aspiration, but it now shares its place with cultural democracy (Touraine, 1998).

The task that democracies have ahead is not easy, as it is shown, in the first place, in the fact that this normative ideal - as it happens with all emerging views - moves forward with intense opposition and controversy.

The institution of marriage between people of same sex, which is nowadays in force in ten countries - among them Argentina, since its sanction by the Congress in July 2010 -, keeps on finding opposition in several industrialized democracies and in most Latin American ones, although civil unions and other ways of recognition of same-sex partnership are more extended.

In democracies such as France, Germany, Great Britain and Spain, between $60 \%$ and $80 \%$ of citizens support the prohibition for Muslim women to wear a veil in public places, including schools, hospitals and government offices (Pew Research, 2010). In April 2011, France put this prohibition legally into effect. The government based it on 
the 'damage' that the practice produces 'on those rules which allow the life in community, ensure the dignity of the person and equality between sexes.' The organisation Amnesty International considered it, on the contrary, a violation to the freedom of religion and expression, but several European countries are studying similar measures (1).

\section{Formation and change in political culture}

In issues such as the recognition of same-sex marriage, the use of the Islamic veil and other cases associated to the value of diversity, the task of democracy is developed in two levels: the sociocultural and the institutional ones. Both dimensions, though interdependent, have their own dynamics.

The political culture belongs to the first dimension and has a deep influence on the functioning of the institutions. The political culture approach implies that the beliefs, values and patterns of behaviour of ordinary citizens have a crucial influence in the course of democracies. The system's stability, depth and effectiveness depend upon the ordinary people - neither only nor mainly on the elites' doings (Inglehart, 1997; Putnam, 1993; Inglehart and Welzel, 2005).

It is not likely that, for example, the political institutions treat and pass a same-sex marriage law if a considerable part of the electorate rejects the unions between people of same sex. In a similar way, the restrictive measures of freedom of expression of Muslim minorities in Europe rely on the weight of intolerance attitudes towards these groups in the rest of the society. The most virulent xenophobic 
attitudes are used to finding concrete political expression in extreme right-wing parties, such as the National Front in France.

Now, the fact that culture has a strong impact on institutions does not mean that there is no influence on the other direction. Most scholars assume that between the cultural and political-institutional spheres there is causal interaction. But due to the fact that culture changes slowly, the key question is to what extent the institutions particularly, the democratic ones - contribute or are able to contribute to that change. Is it possible that, for instance, societies with widespread attitudes of discrimination towards certain groups become more tolerant as a result of life in democracy?

In this matter, the experience of the third wave of democratization - the process of global spreading of democracy which started in the mid 70 s - has given rise to mixed interpretations.

For some scholars, the change's driving force in political culture is economic development (Inglehart and Welzel, 2009). The failures of several new democracies, the fall of some of them as well as the persistence of authoritarian regimes obey to, from this perspective, an economic development which is still insufficient. The citizens that belong to these societies, according to the argument, logically give priority to the satisfaction of their material needs, rather than to the satisfaction of higher-level needs, as greater freedom of choice and political participation - to which tolerance would be also associated. Only when economic modernization - nowadays in progress almost everywhere - increases sufficiently the material well-being, the rise of these higher priorities - or postmaterialist, in terms of this theory - will foster changes in political culture and, as a consequence of that, institutional changes that 
improve or deepen the existing democracy, or establish it where it does not yet exist. (Also the xenophobic reactions in European countries would be owed to a step backwards - possibly temporary - of postmaterialist priorities, generated in a now prolonged economic crisis, in the perception of immigration as a threat to the material welfare of those societies, and in the feeling of insecurity caused by terrorist attacks). Therefore, according to these authors, the political dynamics of the third-wave democracies, though it has some effects on political culture, is not enough to change it significantly, in contrast with the big forces of economic development and technological change.

When concluding his two-decade study about the differences of performance between the Italian regional governments created at the beginning of the 1970s, Putnam (1993) observed likewise that the influence of institutional structure on culture was barely visible after twenty years. On the contrary, it was the particular civic culture of each region the one that seemed to give its stamp to the way its government worked. However, in Putnam's interpretation, what shaped the regional cultures was not economic development. The different associative tradition of each region - specially the one from the North in contrast to the one from the South of Italy - had derived, after several centuries, in very different 'civic communities' or 'social capital stocks', which produced in turn marked contrasts of institutional performance. According to the author, the impact of institutional change on culture could only have substantial effects in the long term.

The transitology paradigm, which arose from the myriad of studies on the democratic transitions of the third wave, emphasized almost exclusively the calculations and 
actions displayed by the elites (O'Donnell and Schmitter, 1991). Culture was not postulated as a factor of great importance. More explicitly, Schmitter and Karl (1991) considered the 'civic culture' subject 'misleading'. The functioning of the new democracies would be based on 'rules of prudence' applied by rational, antagonistic and suspicious actors, rather than on 'deeply ingrained' habits of tolerance, trust, and so. The latter would be a product of democracy, rather than a producer. According to this approach, democratic institutions will be the ones shaping, in the end, a democratic political culture - although, according to what Schmitter and Karl seem to suggest, they could either work without it.

Other authors have a different viewpoint. Diamond (2009) stresses the fact that all democracies - and especially the new ones - need equilibrium between conflict and consensus. Democracy is a system based on the institutionalised competence for power, but a too intense competence may destabilise it. The system, then, requires mechanisms able to mitigate conflict through consensus. This is the role that the 'civic culture' may have in the long term - as it was suggested by Almond and Verba (1963) half a century ago.

By making a balance of the third wave at the end of the 20th century, Diamond (1998) highlighted that in many of those countries the popular support to democracy relied on, beyond the economic problems, a positive evaluation of the political goods provided by the system. The citizens especially valued the new freedoms they enjoyed. There were, then, signs of 'political learning', based on the experience of living under the new system. The cultural and political spheres seemed to have a 
dynamic of their own, with some degree of autonomy regarding the economic dimension.

In a similar way, Torcal (2008) comes to the conclusion that the 'unconditional' support to democracy in Spain could be achieved within a few years, after the transition was completed, through a process of 'adult resocialization' which produced a global and permanent change in the Spanish people's attitudes. According to Torcal, this attitudinal shift was a result of the consensus politics adopted by the main political actors during the democratic transition and consolidation period, which was particularly characterized by the fact of leaving the government 'issue of regime type' out of the electoral battle. The hypothesis assumes that the political elites' strategies may have a fast and deep impact on, at least, some citizens' attitudes - in this case the support to democracy.

In more general terms, the concepts of 'political learning' and 'adult resocialization' mean that political culture may change as a product of the purely political experience and not only as a result of economic development.

Nevertheless, since not all the components of political culture have the same importance, there arises the question about whether the citizens' political experience is capable of changing or shaping its central political attitudes - not only the peripheral ones.

Inglehart (2003) believes that in our era of global spreading of the democratic ideal, citizens from almost all countries - even those with authoritarian regimes - express, when being surveyed, a majority support to democracy. According to Inglehart, this kind of support is a necessary but not sufficient condition for democracy to be able 
either to emerge, stabilize, deepen or be effective. In order to achieve this, other central attitudes would be essential, namely tolerance, trust and especially liberty aspirations (See also Inglehart and Welzel, 2005 and 2009). From the late 20th century, the stagnation - and, in some cases, the retreat - of the processes started in the third wave - which have led some political scientists to talk about a democratic 'recession' - as well as the survival of authoritarian regimes seem to acknowledge him to be right.

Isn't it possible that, in virtue of the same democratic exercise, the citizens learn to be more tolerant, to trust each other more, and to wish more freedom? The answer to this question depends on the one we give to the following question: does the individual's political socialization finish essentially in the early stages of life? Or is it feasible that some central attitudes change during adulthood due to learning? The panel's studies, based on repeated interviews to the same people at different moments of time, say that what prevails is attitudinal stability. Neither are the results completely conclusive nor there are many studies of this type, which need to be prolonged for decades (Krosnick and Alwin, 1989).

It is not infrequent that, for instance, the government and the political system try to promote within the society greater levels of tolerance towards minorities or groups that suffer discrimination. In several cases, these affected groups and the ones who support them normally develop, through civil society's organizations, actions that intend to change the attitudes of defined population segments or of the majority of the citizens. In a more general way, a wide variety of government and civil organizations promote various types of causes with goals which assume a change in the attitudes - 
quite deep-rooted at times - of the sectors which are the target of their campaigns. It is the case of the ecological, pacifist, human rights associations, and the like. Are these efforts forced to achieve superficial changes or, in either case, to activate or reinforce the support of those who already have a favourable predisposition?

This type of actions addressed to specific aims are integrated to the more general process of public opinion formation, in which a broad group of social and political actors with diverging viewpoints take part, and in which the media decisively participate. Conceived as a mechanism of 'collective deliberation', this process - if working reasonably well - can promote, according to Page and Shapiro (1992), the people's 'political education'. From this perspective, political leaders, experts, government officials, social movements, and journalists can contribute to the citizens' education providing information and interpretations about the issues of public interest. It is true that the preferences which are formed in this way in general tend to be consistent with the individuals' previous values and beliefs, since people find themselves likely to be exposed to the messages that agree with their points of view, to perceive and to retain from them the elements which are also concordant, and to interpret the information within their acquaintances, with whom they have many things on common. However, the research on attitudes has set out various mechanisms by which these can change as a result of new data and of social influence processes (De Montmollin, 1985; Perloff, 1991).

Heifetz (1997) correctly observes that, in times of fast changes, entire groups or societies have the need to learn new methods to solve problems or crisis which are framed in complicated and interactive systems. He suggests a set of strategies which 
political and social leaders can apply in order to promote and provide such learning. The strategies are based on giving people back what Heifetz calls the 'adaptive work'.

Since several social crisis or problems involve inconsistencies between reality and people's values, or even a conflict of values, this work usually requires changes in the latter.

To summarize this section, we can postulate three main processes of formation and change in political culture: 1) the cultural tradition and specific historical trajectory of every society; 2) economic development and technological change; 3) political experience and learning. In order to figure out the real influence each one has, it is necessary to carry out empirical research.

\section{Tolerance among Argentineans}

The analysis of the evolution of some tolerance indicators among Argentineans since the restoration of democracy will enable us to clear up a bit the discussion which was set out above. Both the postmodernization theory - developed especially by Inglehart and, more recently, also by Welzel - and the social capital theory, whose main author is Putnam, consider tolerance as one of the central components of the democratic political culture (2).

It is clear that, as it happened when dealing with the matter of diversity, tolerance is not enough to make democracy work. Trust among people - another central element highlighted in both theories - contributes to unity. In their most recent works, Inglehart and Welzel (see, especially, 2005) consider liberty aspirations as the most important component in democratic culture. To the three aspects already shown, they add elite- 
challenging, self-directed participation, among whose main expressions we can find petitions and demonstrations. The four of them are integrated in an interrelated system called self-expression values (3).

Tolerance is particularly interesting for us since it has not taken part in the political tradition of Argentineans. Briefly after democracy was restored, Portantiero (1984) wrote that, although immigration made Argentina an egalitarian society, it was not enough to 'shape a democratic political culture, self-sustained in tolerance' (page 142). Cavarozzi (1983) did not thought of the outlook which was marking the beginning of the new-born democracy as 'so promising', since at the moment of the coup d'état which took place in 1976 'the Argentinean society was deeply imbued in antidemocratic values and habits: the cult of violence, (...) the lack of tolerance to dissident behaviours and ideas and critical thinking, and disdain for consensus' (pages 69-70).

Our analysis will focus on the trajectories followed by three specific indicators, oriented to tolerance towards homosexuals, people suffering from AIDS and individuals with criminal records. The selection does not only come from the availability of time series of data about these indicators for relatively long periods. It also relies on the fact that the contrasts and similarities of its courses enable us to reach to significant hypothesis about some key mechanisms which seem to influence the increase and decrease of tolerance.

Moreover, as it is one of the most discriminated groups in most countries, attitudes towards homosexuals are considered one of the best 'acid tests' of tolerance within a society (Inglehart, 2003). In international comparative studies, tolerance towards 
homosexuals shows a strong positive correlation with democracy's stability and effectiveness.

When examining the reasons for Argentina being one of the first countries in the world - the second in the Americas - to include in its own civil code the figure of same-sex marriage, Corrales and Pecheni (2010) particularly highlight the existence of a catholic population which in its majority is not active, the absence of religious parties or parties closely related to churches, the tradition of importing legal rules and the rich internal legislative agenda associated with human rights.

But at the same time we can see a cultural long-term change associated with the spreading of tolerance attitudes in the Argentinean society, which is possible to check over the last three decades. There are, however, particular cases which deviate from that general trend - and which are also instructive about the mechanisms at stake. In order to measure tolerance, a list of social groups is shown to the person surveyed, and he/she is asked whether he/she would not like to have any of such groups as neighbours. Figure 1 shows the evolution in the percentage of population who mentioned the three groups analysed in this article. The data from the period 19842006 represent the whole country and they arise from our calculations which were taken from the World Values Survey's databases coordinated by Inglehart. The percentages of the years 2008 and 2010 belong, respectively, to the region of Gran La Plata and the city of Junín, both located in the province of Buenos Aires (4). These come from two research projects about political culture directed by the author of this article (5). 
Figure 1 - Evolution of Tolerance Indicators in Argentina Groups that people would not like to have as neighbours $\%$ of population

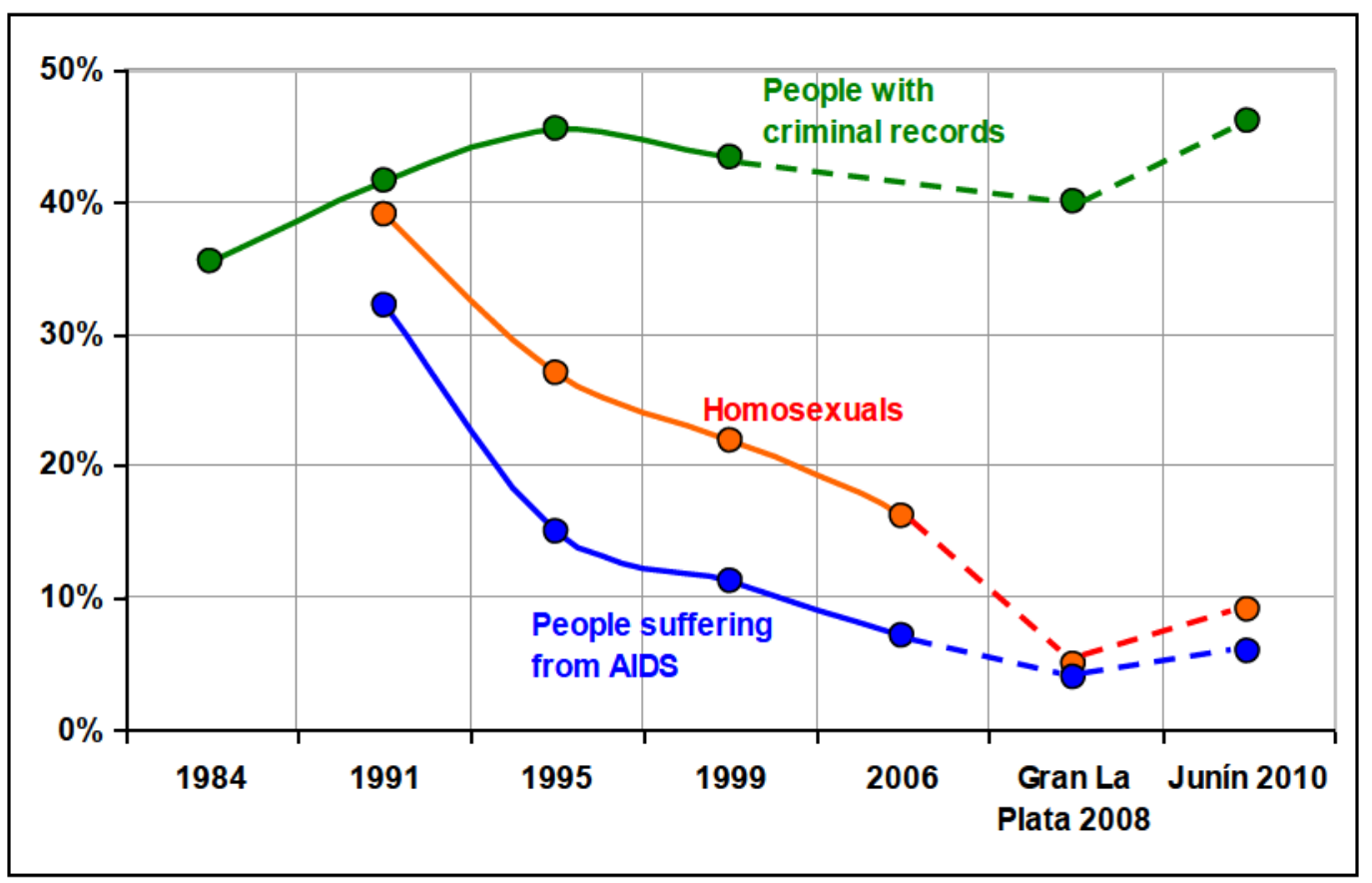

Source: 1984.2006: own calculations for the whole country from the World Values Survey's database. 2008 and 2010: Research Projects PID-P001 - Universidad Nacional de La Plata (UNLP) and P-0415 Universidad Nacional del Noroeste de la Provincia de Buenos Aires (UNNOBA). N: 1984=1.005; $1991=1.002 ; 1995=1.079 ; 1999=1.280 ; 2006=1.002 ; 2008=400 ; 2010=400$.

We can clearly see a deep and sustained drop in the proportion of Argentineans who pick homosexuals and people suffering from AIDS, which is a trend that reflects a noticeable rise of tolerance in a term of two decades. In 1991, the time series' starting point for both groups, $39 \%$ of Argentineans did not want to have homosexual neighbours. The figure had dropped to $16 \%$ in 2006 and in our survey studies it had further declined to $5 \%$ in Gran La Plata (2008) and to 9\% in Junín (2010). This 
significant change is the background of the same-sex marriage law's treatment and approval in the middle of 2010.

Attitudes towards people suffering from AIDS show a similar course. The percentage of people who did not want them as neighbours drops from $32 \%$ in 1991 to $7 \%$ in 2006. In 2008 and 2010, it was 4\% in Gran La Plata and 6\% in Junín.

The phenomenon observed in relation with people with criminal records is totally different. In that case, tolerance tends to decrease. While in $1984,36 \%$ of Argentineans pointed at this group, in 1999 - last point in the national series - that figure went up to $43 \%$. In $2008,40 \%$ of people from La Plata picked this group and in $2010,46 \%$ of people from Junín did the same. The background here is undoubtedly the rise of the issue of insecurity and crime in the public agenda.

This latter fact is significant since there are just a few social groups or categories with so high levels of discrimination. For example, $36 \%$ of Argentineans pointed at the alcoholics in 2006 , and $31 \%$ of people from La Plata pointed at the drug-addicts in 2008. With not at all insignificant, but much lower figures, there appear Korean and Chinese people - which record $12 \%$ in Junín in 2010 and 9\% in Gran La Plata in 2008 -, while Muslims record 6\% in 1999 all over the country.

As regards the international aspect, tolerance towards certain social groups is associated with the particular history and culture of each society, but also to its economic development levels. The postmodernization theory underlines especially this point. According to this approach, economic modernization is closely associated with stable and effective democracy through the changes it produces in culture and social structure. 
It is necessary to refer back to this theory - which approaches democracy from the long-term social change perspective - both due to its high degree of formalization and predictive power and due to the extraordinary database - the World Values Survey on which it supports: 350 thousand interviewees with standardized questionnaires from 1981 to 2008 , belonging to more than 90 countries from every continent.

As different authors have highlighted from the 1950s, economic modernization generates a set of transformations which are favourable to the emergence of democracy. The extension of wealth reduces social distances; education is generalised; the mass media's development provides everyone with information about Politics, which in the past used to be kept only for the elites; the citizens, who have at their disposal more education, information and organisation skills acquired in more and more sophisticated workplaces, develop a greater capacity for political and civic action.

The theory which we are dealing with particularly studies the pro-democratic cultural changes which economic development produces when entering its most advanced phase, i.e., the postindustrial society (Inglehart, 1997 and 1990; Inglehart and Welzel, 2005). The main mechanism which links economic transformation with value change is based on the Maslow's hypothesis about the individuals' needs, which are organised in a hierarchy. Survival needs - both physiological and physical-safety must be reasonably satisfied before people give priority to higher-level needs, such as esteem, belonging and self-expression. Once development has sufficiently improved material well-being, in a way which a growing number of individuals take 
their survival for granted and develop a sense of security, materialist priorities will start to lose ground to postmaterialist ones.

Now, since the individuals' personality nucleus - including their basic values - is shaped in their pre-adult life and remains stable from that moment on, the fact of an individual's priorities being materialist or postmaterialist will depend upon the degree of subjective security or insecurity with which he/she grew up.

The notion of a needs hierarchy, combined with this socialization hypothesis, implies that if a society moves forward in terms of a sustained economic development, young and old generations will have different value priorities. The change in society's values - from the materialist priorities to the postmaterialist ones - is going to be produced as younger generations replace the old ones. There will be short-term fluctuations: an economic crisis will cause a general and temporary drop of postmaterialist priorities, but the long-term trend will not be altered, unless society reverts its material course permanently.

The fact of perceiving the own existence as secure or insecure has a wider impact on a broader set of cultural norms: Politics, religion, family, work, lifestyles are deeply affected. The value of the new and exotic - and therefore the tolerance towards individuals and groups seen as such - is one aspect of this cultural shift.

The change oriented towards the postmodern values - of which the postmaterialist values are part - became visible in several countries from the 1960s. The young people at that time transformed habits, challenged authority and asked for a more participative democracy. Materialist and postmaterialist priorities have been measured in surveys from the 1970 s and make up a well-documented process. 
According to Inglehart, postmodern values are essentially pro-democratic. Industrialisation may or may not lead to democracy, but advanced economic development, which makes this value system emerge, makes highly probable its establishment or deepening. Aspirations of freedom, individual autonomy or selfexpression, which arise from the experienced feeling of safety at early age, are the core of such system. Existential insecurity leads the individuals to take refuge in relatively closed groups made up of similar people who tend to mistrust and discriminate strangers. On the contrary, certainty leads us to see the world as a safe place, to trust others and to see them as intrinsically valuable individuals. In this way, generalised trust and tolerance arise. People establish social links which are not motivated by group conformity, but by their free choice. Peculiar ways of civil and political organisation emerge, such as elite-challenging, self-directed political activity. Here, we will not go deep into all these relationships, but we must investigate whether tolerance among Argentineans is or is not related to postmaterialist priorities. The most widely used indicator to measure the postmaterialist/materialist dimension is an index which arises from showing the interviewees a list of four goals which the country should set for the next ten years, and ask him/her which one, in his/her opinion, is the most important as well as which one follows it. The objectives are: maintaining order in the nation, giving people more say in important government decisions, fighting rising prices, and protecting freedom of speech. People who choose participation in government decisions and freedom of speech - both related to freedom aspirations - are classified as postmaterialist; the ones who pick order and prices are materialist; the others are considered mixed. 
The evolution of this index in Argentina, since 1984, is shown in Figure 2. The percentage of postmaterialists traces out a parabola. In 1984 it is $13 \%$, goes up to a maximum of $30 \%$ in 1995 , and goes down to $14 \%$ in 2006 . The proportion of materialists has an inverse trajectory in a concave way. It goes from $33 \%$ in 1984 down to a minimum of $16 \%$ in 1995 and increases again up to $31 \%$ in 2006 . The percentage of mixed people - which combines a postmaterialist and a materialist goal - remains constant around $55 \%$. In our surveys, in 2008 the society from Gran La Plata appears a bit more postmaterialist than the previous national average, which is similar to the one registered in the city of Junín in 2010.

Figure 2 - Postmaterialists and Materialists in Argentina $\%$ of population

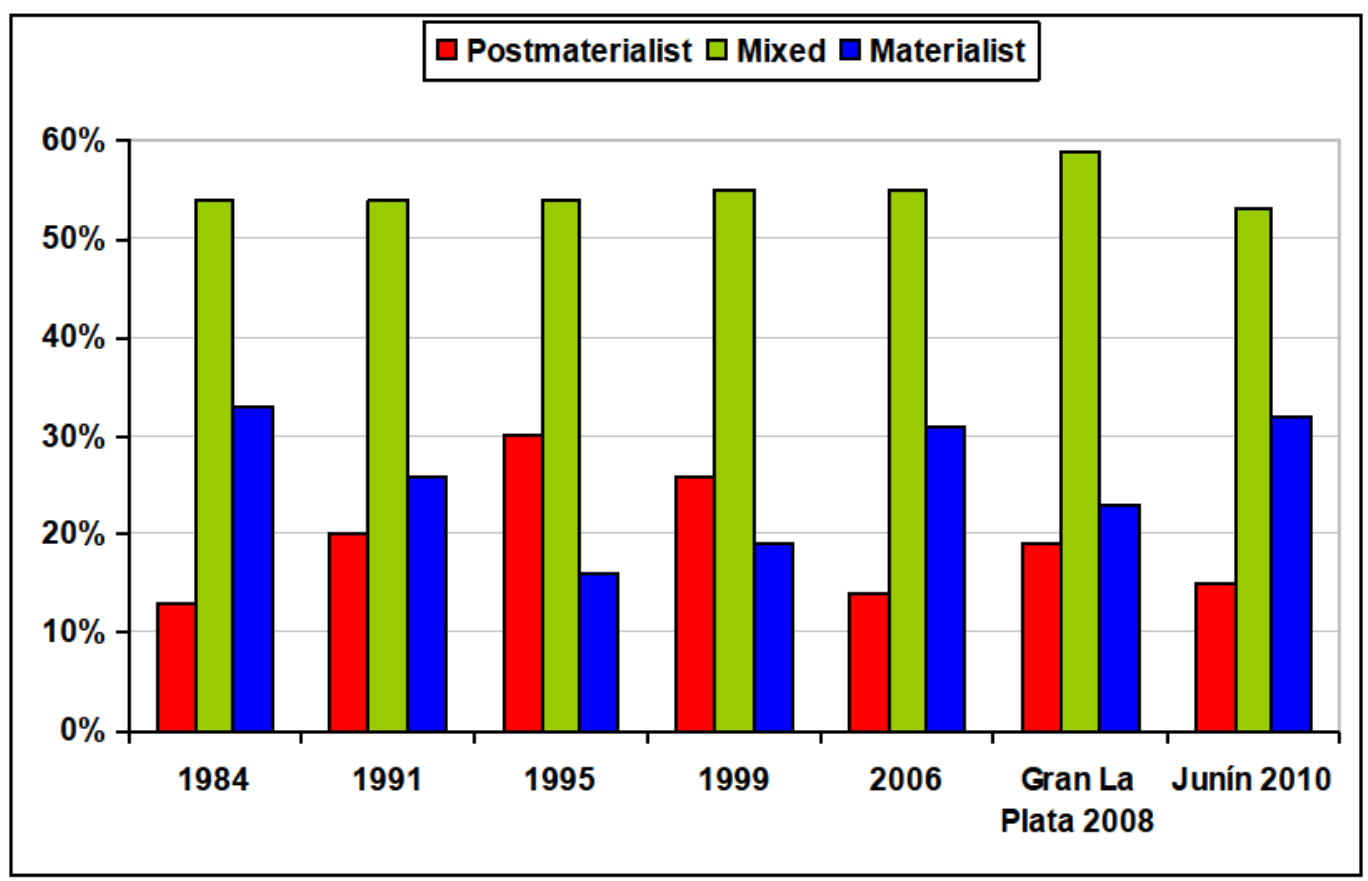

Source: 1984.2006: own calculations for the whole country from the World Values Survey's database. 2008 and 2010: Research Projects PID-P001 (UNLP) and P-0415 (UNNOBA). 
According to the theory's predictions, we should expect the postmaterialists to be more tolerant - and the materialists to be less tolerant - towards the different social groups, while the mixed groups are in the middle of both. From the transnational surveys we can see that, for instance, postmaterialists are more open-up to homosexuals in almost every society. We will immediately prove that, indeed, this is the case. However, we can henceforward notice that the trajectories followed by our three tolerance indicators do not coincide with the one followed by the postmaterialism index. In Figure 3 we can see the evolution of the percentage of Argentineans - classified according to the postmaterialism index - who would not like homosexuals 'as neighbours'.

Figure 3 - Argentina: People who would not like homosexuals as neighbours $\%$ of population

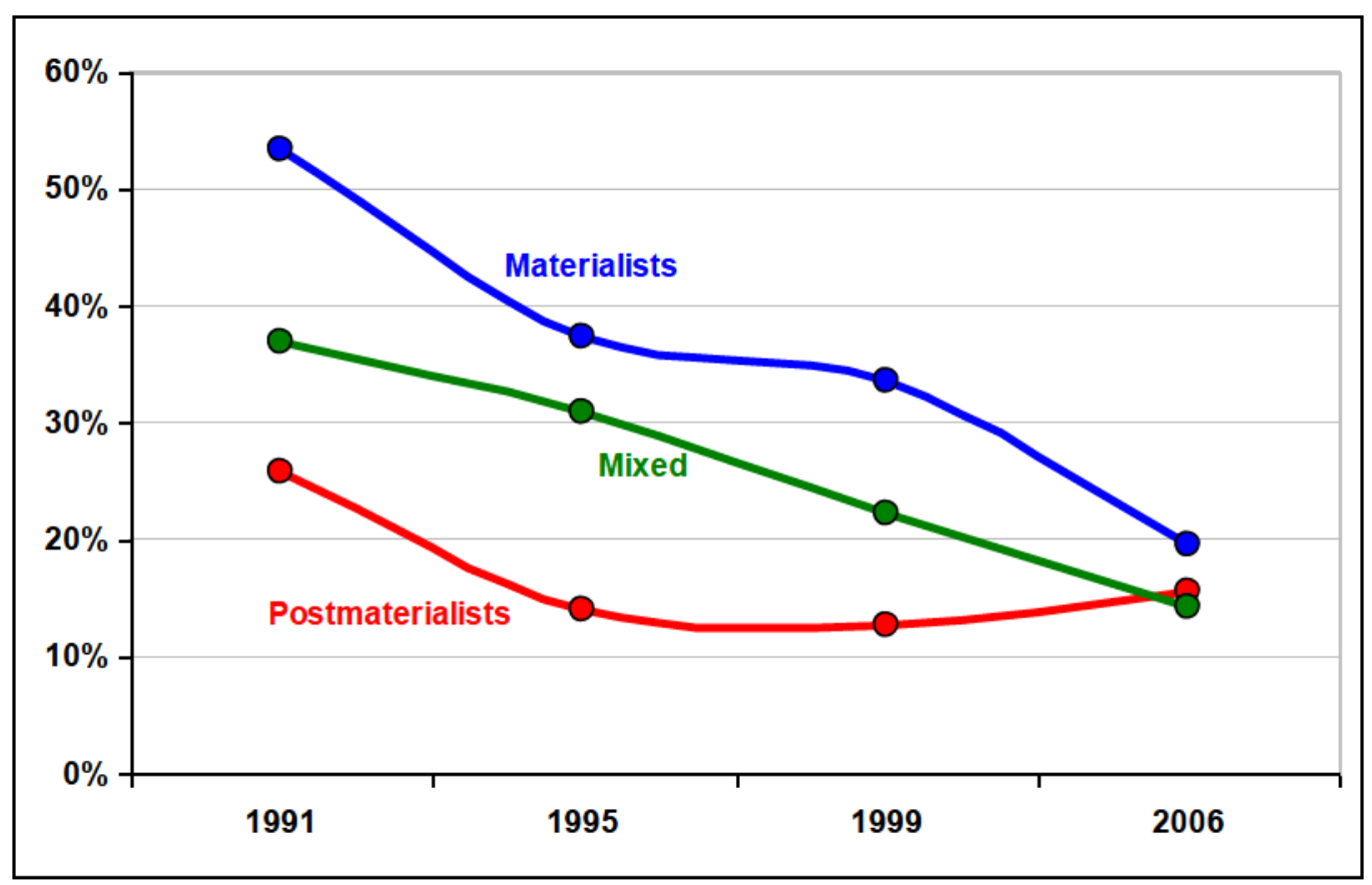

Source: Own calculations for the whole country from the World Values Survey's database. 
Three aspects from the graphic are especially noticeable: a) the tolerance systematic differences among postmaterialist, materialist and mixed groups in the period from 1991 to 1999 , which coincide with the theory's predictions; b) the continuous decrease of the percentage that discriminates homosexuals in all three categories; c) the virtual disappearance of tolerance differences between postmaterialist and mixed groups in 2006 while the materialist group being just slightly less tolerant. In 1991, $53 \%$ of materialists did not want to have homosexual neighbours, opposed to $26 \%$ of postmaterialists. In 2006 , the figures had reduced down to $20 \%$ of materialists and $16 \%$ of postmaterialists. This means that the postmaterialists who discriminate homosexuals dropped by $40 \%$ while the materialists by $63 \%$.

It is absolutely clear, then, that the substantial fall of the percentage of Argentineans who discriminate homosexuals is not explained by a rise in postmaterialism or a reduction of materialism in the long term. The postmaterialist / materialist dimension follows, as we have seen, a curvilinear trajectory, which in 2006 ended up making the proportions of postmaterialists and materialists go back to the levels of 1984 . On the contrary, the percentage of population who discriminates homosexuals drops constantly, and it also does so in the three categories of the postmaterialist / materialist dimension. 
Figure 4 - Argentina: People who would not like people suffering from AIDS as neighbours

$\%$ of population

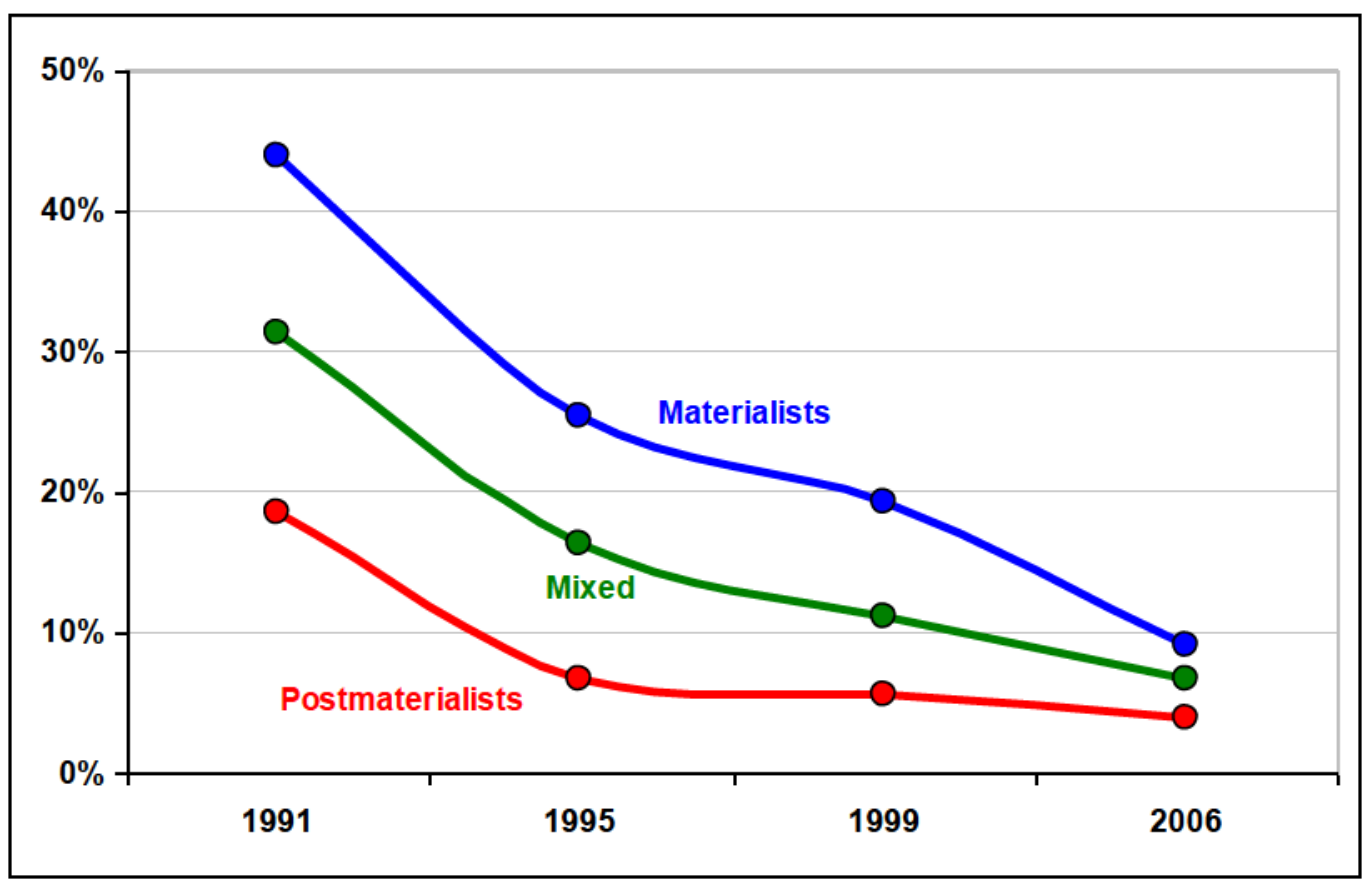

Source: Own calculations for the whole country from the World Values Survey's database.

The same phenomenon has taken place in the case of the attitudes towards people suffering from AIDS, as we can see in Figure 4. In 1991, 44\% of materialists and 19\% of postmaterialists discriminated this group; in 2006 , only $9 \%$ of materialists and $4 \%$ of postmaterialists did so. It is remarkable that both groups have dropped by $79 \%$.

The attitude towards people with criminal records follows a different, but not less suggestive, pattern (Figure 5). Here, the points to highlight are: a) discrimination increases in the three categories of the postmaterialist/materialist dimension; b) there are clear tolerance differences among the three categories, according to the theory's predictions; c) but the increase of intolerance among postmaterialists ( $48 \%$ between 
the starting and ending points) is much higher that the one registered among materialists (25\%) and mixed (23\%). In $1984,39 \%$ of materialists and $26 \%$ of postmaterialists did not want neighbours with criminal records; in 1999, the figures were $49 \%$ and $38 \%$, respectively.

Figure 5 - Argentina: People who would not like people with criminal records as neighbours

$\%$ of population

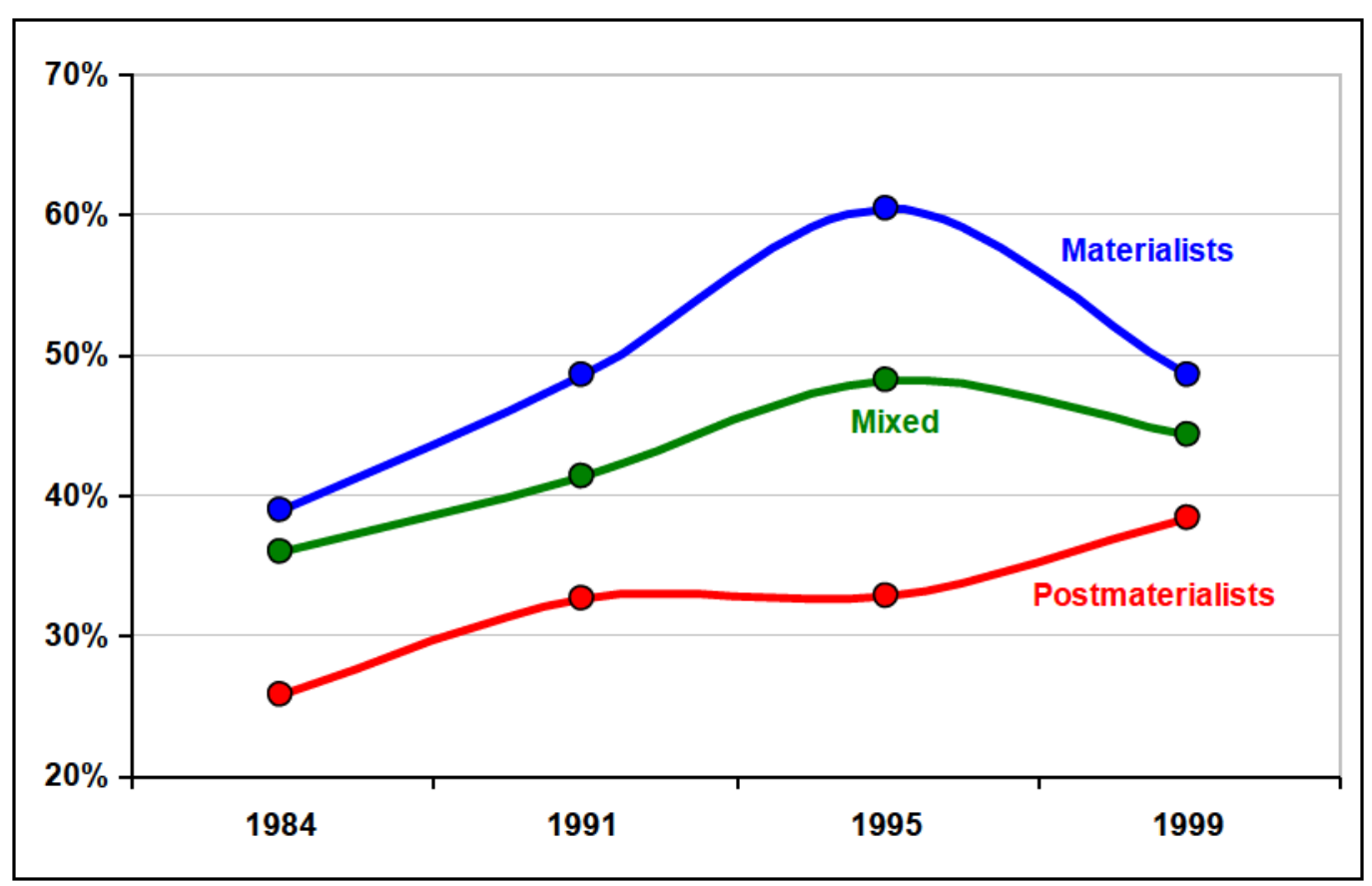

Source: Own calculations for the whole country from the World Values Survey's database.

In our survey studies carried out in Junín and Gran La Plata, we can find similar patterns to the ones found in the national level as regards the tolerance differences among postmaterialists, materialists and mixed (Figure 6). In Gran La Plata, these differences are really slight - although they do not disappear - for homosexuals and 
people with AIDS. In both communities, however, postmaterialists discriminate people with criminal records a lot less than materialists do.

Figure 6 - Junín 2010 and Gran La Plata 2008

Groups that people would not like 'as neighbours'

$\%$ of population

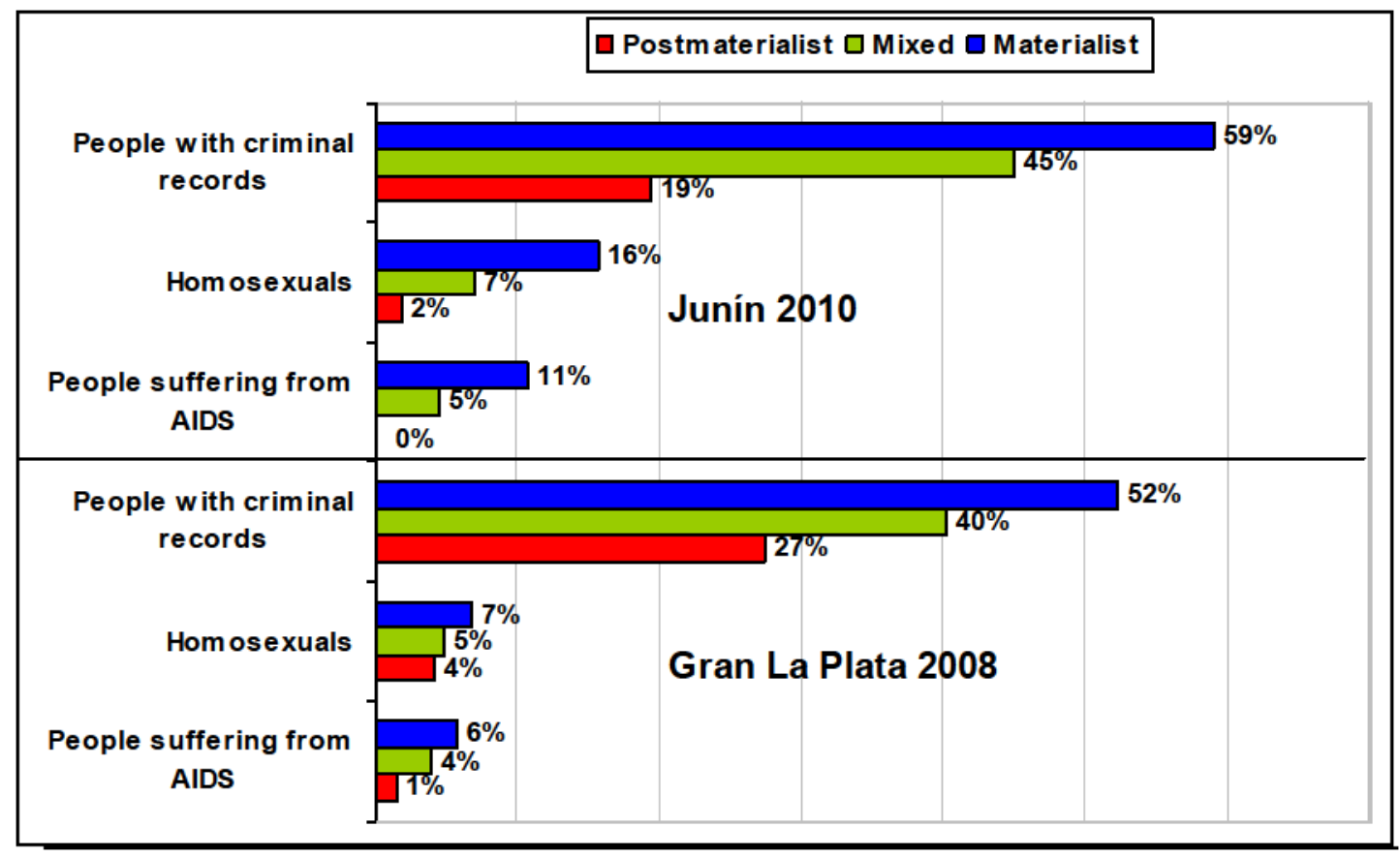

Source: Research Projects PID-P001 (UNLP) and P-0415 (UNNOBA).

\section{The task of democracy}

The postmaterialist / materialist dimension reflects the impact of economic development on the cultural sphere. And this, undoubtedly, constitutes a factor of enormous importance when analysing the emergence, stability, depth and effectiveness of democracy. 
In his historical assessment about democracies in Latin America, Rouquié (2011) has pointed out the way in which those 'non-tocquevillian republics' - in which the 'equality of conditions', which according to De Tocqueville was a feature of a democratic society, has never prevailed - have always shown the tension existing between their long tradition of the principles of freedom and pluralism - no others were the ones proclaimed in order to legitimize the independence movements - and their 'non-egalitarian and hierarchical, eminently adverse for democratic practice' social structures (page 346). If democracy is nowadays moving forward in the region - Rouquie adds -, it is 'because societies are transforming'. They are more urbanized and secularized, class divisions are less pronounced, exclusion is decreasing, education and information are spreading (ibid.).

But modernization, although it is probably the most important force, does not explain it all. On one hand, also cultural tradition exerts influence. In this way, Rouquié points out that, despite the turbulences which distinguish the two centuries of existence in Latin American countries, 'the flame of democracy never extinguished'. On the other hand, democracy is also 'an uncertain, complex cultural construction which moves forward by trial and error' (page 345).

Our analysis about the evolution of tolerance in Argentina, though only approached in some indicators, shows that the task of cultural construction of democracy has tangible effects. In the case of homosexuals and people suffering from AIDS, the increase of tolerance is clearly related to a process of collective deliberation - an essential part of democratic exercise since the restoration of Argentinean institutions in 1983 - which gradually changed the discriminatory attitudes towards such groups. 
Postmodernization theory captures an important aspect of reality, as it is reflected on the systematic differences that are present in the tolerance attitudes we can see among postmaterialists, materialists and mixed. Likewise, in another work (Jorge, 2010, pages 173-176), we have pointed out that the successive Argentinean generations differ in the relative weight of postmaterialists and materialists, following, in general terms, the theory's predictions. In the period between 1984 and 2006, covered by the World Values Survey, the cohort of Argentineans who were born between 1970 and 1979 is more postmaterialist than the group born between 1950 and 1959, which is, in turn, more postmaterialist than the cohort born between 1940 and 1949. This age-decreasing postmaterialism pattern continues with the Argentineans who were born in the 30s, 20s and 10s. The 1960-1969 cohort is the most postmaterialist of all, until 1995, but later it is less postmaterialist than the ones who were born in the periods $1970-1979$ and 1950-1959.

As we can predict, the different Argentinean generations show tolerance differences, which partly reflect the weight postmaterialists and materialists have. In Figure 7 , which illustrates this fact in the case of homosexuals, the youngest Argentineans though the lines intersect at some points - tend to be more tolerant than the older generations. However, the percentage of those who would not like to have homosexual neighbours decreases throughout the period in almost every cohort. 
Figure 7 - Argentina: People who would not like homosexuals 'as neighbours' by Age Cohorts

$\%$ of population

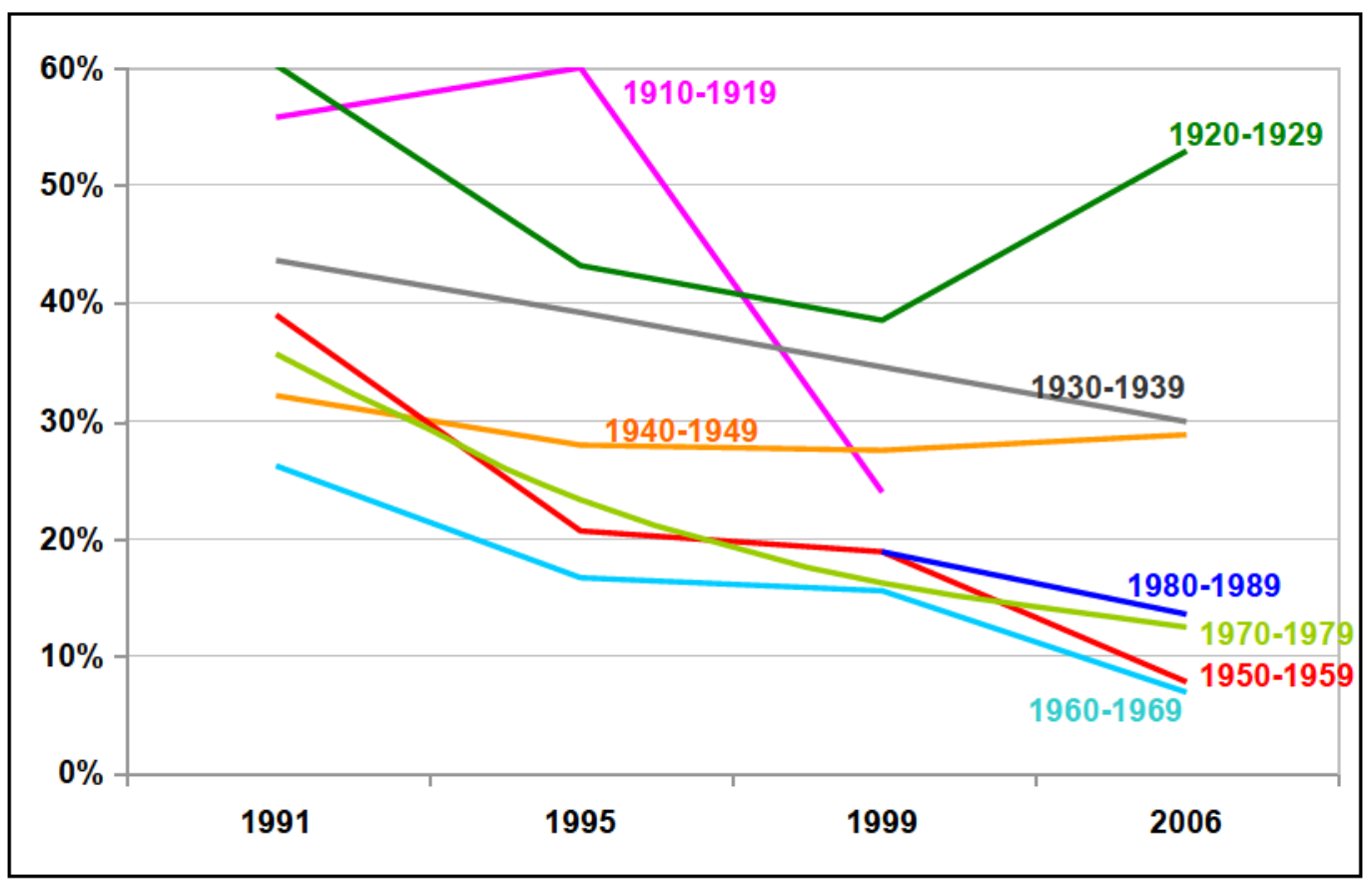

Source: Own calculations for the whole country from the World Values Survey's database.

From the graphic, we can clearly see that the increase of tolerance towards homosexuals is not explained mainly by generational replacement - we could prove the same for people suffering from AIDS. The central mechanism, unforeseen in the postmodernization theory, seems to be what we have called 'adult resocialization' or 'political learning'.

We have applied the procedure suggested by Inglehart (1990, page 99) to the data in Figure 7 in order to calculate the magnitude of value change owed to generational replacement (6). Taking 1991 as starting point, when eliminating the influence of the younger generations, the proportion of Argentineans who would not like to have 
homosexual neighbours increases from $16 \%$ to $20 \%$ in 2006 . In other words, even without the natural replacement of the successive generations, between 1991 and 2006 the percentage of Argentineans that discriminate homosexuals would have dropped by 19 percentage points, from $39 \%$ to $20 \%$. Actually, it dropped by 23 percentage points - from $39 \%$ to $16 \%$-, i.e., just 4 more. This $4 \%$ represents all the contribution that generational replacement has made to the increase of tolerance towards homosexuals. The rest must be ascribed to adult resocialization.

The indicators analysed in this chapter point out that the process of 'collective deliberation' has an important role in this learning process. Since the restoration of democracy, the public deliberation on the issue of homosexuality, though it has generated several controversies, gradually tended to fight discriminatory attitudes, especially in the media and the policies implemented by the government. Moreover, civil organisations and groups defending the Lesbians, Gays, Bisexuals and Transsexuals' rights (LGBT) developed an intense agenda based on transnational legislation and the precedents of the country itself as regards human rights, as well as in a legal and legislative action strategy which proved its effectiveness.

The support of the government party to the aspirations of LGBT groups ended up making Argentina become one of the first nations to legalize same-sex marriage. Probably, in the sphere of human rights, political learning in Argentina may have created appropriate conditions to move forward in that direction. At least in this case, the fact of having undergone a military dictatorship may represent an advantage, as long as the society has learned anything from that experience. 
The short list of countries which have passed the same-sex marriage so far points out an interpretation which coincides with the preceding arguments. The Netherlands, Belgium, Canada, Sweden, Norway and Iceland are among the world more advanced nations as regards economic and human development. Except for the particular case of Iceland, they are likewise among the societies in which postmaterialist values are more widespread. In the other four countries - Spain, Portugal, Argentina and South Africa - materialist values prevail to a greater extent. But the three first countries underwent the experience of long and bloody dictatorships, and the fourth one, had an apartheid regime which likewise violated the most basic human rights.

The issue of AIDS has also been object of coherent government policies, informative campaigns and reasonable discussion in Argentina. It is about a matter in which prejudices based on the lack of information can be changed by means of a good public debate.

On the contrary, the process of collective deliberation about crime and insecurity never worked appropriately in Argentina. It has suffered from opaque information, confusing debate and swinging public policies. Growing fear of crime - a result of both the real increase of insecurity and people's confusion - and the 'tough on' rhetoric prevalent during long periods have naturally tended to feed the intolerance attitudes.

Although the deliberative mechanisms of democracy may fail - as the case of people with criminal records reveals -, political learning seems to be able, in some circumstances, of becoming a transforming force of the people's political culture. 


\section{Footnotes:}

(1) See, for example, The Guardian: 'Full-face veils outlawed as France spells out controversial niqab ban', 3 March, 2011. CNN.com: 'French senate approves burqa ban’, September 14, 2010. El País: ¡Cómo legisla Europa sobre el velo’ [How Europe legislates on the veil, 20 April, 2010.

(2) For a general explanation of these theories, see Jorge, 2010, especially Chapter 2.

(3) In addition to trust and tolerance, Putnam adds civic engagement, political equality, solidarity, and civil associations (1993, pages 86-91). Other social capital scholars also highlight respect for the law and civic norms. Some democracy theorists consider that the main cultural elements are unconditional support to the system i.e., its legitimacy - and confidence in institutions.

(4) The city of La Plata is capital of the Province of Buenos Aires, the most populated state and the one with more economic weight in Argentina. The Gran La Plata region, which comprises the city and the two neighbouring towns of Berisso and Ensenada, has a population of 750 thousand inhabitants. The city of Junin, the most important one in the northwest of the same province, is located in the core of the intensive agricultural area of the country, and has 86 thousand inhabitants.

(5) The Projects are PID-P001 'Comunicación y Cultura Política en la Región del Gran La Plata' [Communication and Political Culture in the Gran La Plata Region] (Universidad Nacional de La Plata, 2006-2008) and P-0415 'La Cultura Política en el Noroeste Bonaerense' [Political Culture in the northwest of Buenos Aires] (Universidad Nacional del Noroeste de la Provincia de Buenos Aires, 2008-2011). 
(6) The procedure consists in keeping the proportion of interviewees of each cohort fixed over the total amount of interviewees registered in 1991. In 1995, 1999 and 2006, the new cohorts are left out and the observed percentage that discriminates homosexuals in each of the other cohorts is multiplied by the weight of these cohorts in 1991.

\section{Bibliography}

Almond, Gabriel, and Sidney Verba (1963): The Civic Culture: Political attitudes and democracy in five nations, Princeton University Press, Princeton.

Cavarozzi, Marcelo (1983): Autoritarismo y democracia (1955-1983), Centro Editor de América Latina, Buenos Aires.

Corrales, Javier, and Pecheny, Mario (2010): 'Six Reasons Why Argentina Legalized Gay Narriage First', Americas Quarterly, July 30, http://www.americasquarterly.org De Montmollin, Germaine (1985): 'El cambio de actitud', en Moscovici, Serge (comp.), Psicología Social I, Paidós, Barcelona, pp. 117-173.

Diamond, Larry (2009): 'Three paradoxes of Democracy', in Diamond, Larry, and Plattner, Marc F. (eds.): Democracy. A Reader, The John Hopkins University Press, Baltimore pp. 73-85.

Diamond, Larry (1998): 'Political Culture and Democratic Consolidation', Working Paper 1998/118, Instituto Juan March, Madrid.

Heifetz, Ronald A. (1997): Liderazgo sin respuestas fáciles. Propuestas para un nuevo diálogo social en tiempos difíciles, Paidós, Barcelona. 
Inglehart, Ronald (2003): 'How Solid Is Mass Support for Democracy: And How Can We Measure It?', Political Science and Politics, Vol. 36, N 1, pp. 51-57

Inglehart, Ronald: Modernization and Postmodernization (1997): Cultural, Economic, and Political Change in Forty-Three Societies. Princeton University Press, Princeton. Inglehart, Ronald (1990): Culture Shift in Advanced Industrial Society, Princeton University Press, Princeton.

Inglehart, Ronald, and Welzel, Christian (2009): 'Development and Democracy: What We Know about Modernization Today', Foreign Affairs, March/April, pp. 33-41.

Inglehart, Ronald, and Welzel (2005), Christian: Modernization, Cultural Change, and Democracy. The Human Development Sequence, Cambridge University Press.

Jorge, José Eduardo (2010): Cultura Política y Democracia en Argentina, Edulp, La Plata.

Krosnick, Jon A., and Alwin, Diane F. (1989): 'Aging and Susceptibility to Attitude Change', Journal of Personality and Social Psychology, Vol. 57, № 3, pp. 416-425.

O'Donnell, Guillermo, y Schmitter, Philippe C. (1991): Transiciones desde un gobierno autoritario. Conclusiones tentativas sobre las democracias inciertas (Volumen 4), Paidós, Buenos Aires.

Page, Benjamin I. and Shapiro, Robert Y. (1992): The Rational Public. Fifty Years of Trends in American's Policy Preferences, The University of Chicago Press, Chicago Perloff, Richard (1991): 'Psychological Dynamics of Political Advertising Effects', Political Communication and Persuasion 8 (4), pp. 213-219.

Pew Research Center (2010): 'Pew Global Attitudes Project: Widespread Support for Banning Full Islamic Veil in Western Europe', July 8, http://pewresearch.org 
Portantiero, Juan Carlos (1984): 'Condiciones para un nuevo pacto institucional en la Argentina', en Oszlak, Oscar y otros: 'Proceso. Crisis y transición democrática', Vol. 2, Centro Editor de América Latina, Buenos Aires, pp. 133-144.

Putnam, Robert D. (2007). 'E Pluribus Unum: Diversity and Community in the Twentyfirst Century. The 2006 Johan Skytte Prize Lecture', Scandinavian Political Studies, Vol. $30, \mathrm{~N}^{\circ} 2$, pp. $137-174$.

Putnam, Robert D. (1993): Making Democracy Work: Civic Traditions in Modern Italy. Princeton University Press, Princeton.

Rouquié, Alain (2011): A la sombra de las dictaduras. La democracia en América Latina, FCE, Buenos Aires.

Schmitter, Philippe C., and Karl, Terry L. (1991): 'What Democracy Is... and Is Not', Journal of Democracy, Summer, pp. 67-73.

Torcal Loriente, Mariano (2008): ‘El origen y la evolución del apoyo a la democracia en España. La construcción del apoyo incondicional en las nuevas democracias', Revista Española de Ciencia Política, № 18, Abril, pp. 29-65.

Touraine, Alain (1998): ¿Qué es la democracia?, Fondo de Cultura Económica, Buenos Aires.

Uslaner, Eric (2009): 'Trust, Diversity, and Segregation', Social Science Research Network, December 15.

http://papers.ssrn.com/sol3/papers.cfm?abstract_id=1523721 